\title{
Investigate the Challenges and Opportunities of Female Headed Households and Women Farmers in Male-Headed Households in Non-Agricultural Livelihood Diversification Strategies: The Case of Shebel Berenta District, Amhara Region, Ethiopia
}

\author{
Eyayu Kasseye Bayu \\ Department of Gender and Development Studies, College of Social \\ Science and Humanities, University of Gondar, Ethiopia
}

\begin{abstract}
*Corresponding author
Eyayu Kasseye Bayu, Department of Gender and Development Studies, College of Social Science and Humanities, University of Gondar, Ethiopia
\end{abstract}

Submitted: 26 Jan 2021; Accepted: 08 Feb 2021; Published: 16 Feb 2021

citation: Eyayu Kasseye Bayu (2021) Investigate the Challenges and Opportunities of Female Headed Households and Women Farmers in Male-Headed Households in Non-Agricultural Livelihood Diversification Strategies: The Case of Shebel Berenta District, Amhara Region, Ethiopia. International Journal of Women's Health Care 6(1): 105-118.

\begin{abstract}
It is universally accepted as the fact that agriculture sector is incapable of creating sufficient gainful employment, food security and spurring economic growth in rural areas of developing countries. Even if our country Ethiopia practice agriculture for a long period, expected outcome is not attained on a sustainable basis to the livelihood of the households and food insecurity until now a day due to limited attention for the high potential of the non-farm sector in the government policies and strategies. Similarly, the challenges and opportunities of women headed households and male headed households in non-agricultural livelihood diversification strategies still uncovered in the rural economy of Ethiopia. Therefore the purpose of this study was to explore the challenges and opportunities of women headed households and male headed households in non-agricultural livelihood diversification in case of Shebel Berenta Woreda. Qualitative research method with the case study design was employed for data collection and data analysis. Qualitative data were collected from 10 interviewees, seven key informants, 28 focus group discussants and observation and the data analyzed via thematically. The result revealed that negative outlook to handicrafts, shortage of working capital, limited market demands, the absence of institutional support, lack of skill training, absence of technology, and laws and regulation were challenges women faced to participate in NFA. While, the presence of family support, natural resources, business plan preparation and mutual support in their own association where the opportunities for women to participate in NFA. In line with the problems identified, the local government should work on awareness creation and education, provision of support, built local infrastructure, provision of credit and training.
\end{abstract}

Keywords: Diversification Strategies, Female Headed Households, Livelihood, Male Headed Household, Non-Agricultural

\section{Background}

Agriculture is an important sector for the majority of the rural populations' livelihood in developing countries. It has been the predominant activity for most rural households in Sub-Saharan Africa (SSA) that offers a strong option for spurring growth, overcoming poverty and enhancing food security [1]. However, farming as a primary source of income has failed to guarantee sufficient livelihood for most farming households in Sub-Saharan Africa countries [2]. This is because the agricultural sector is facing a serious of challenges such as low productivity, inadequate investment, changes in climatic conditions, postharvest losses, diseases and pest infestation in developing countries [3]. By implication, agriculture cannot support livelihoods in many developing countries and transitional economies on a sustainable basis and therefore diversification of livelihoods is critical $[4,5]$.

Cognizant with the above, one of the ways subsistence households diversifies their livelihoods is through pursuing non-farm activities $[6,7]$. According to MOFA the non-farm sector plays a critical role in poverty reduction, consumption expenditure and food securi- 
ty especially in developing countries [8]. The contribution of the rural non-farm activities alone is $30-40 \%$ in South Asia, 40-45\% in Latin America, South East Asia, and Sub-Saharan Africa. Including urban income, total rural non-farm activity contributions may be closer to $70 \%$ in some cases [9]. However, there is a wide difference between literatures regarding the share of non-farm income in total household income in Ethiopia. Barrett and Reardon reported that the share of non and/off-farm income in rural Ethiopia averaged about $36 \%$ in $1989 / 90$ fiscal year [10]. On the other hand, Reardon et al., found that the non - farm share of total income in rural Ethiopia was about 20\% in 1999 fiscal year [11]. Despite the differences in the percentage of income share derived from non-farm employment, the role of non-farm income in total household income is significant.

The non - farm sector is also an important source of employment for rural women [12]. Nevertheless, around the world, resilient and resourceful rural women contribute in a multitude ways through different livelihood strategies to lifting their families and communities out of poverty. They work as unpaid and own-account or self-employed on-farm and non-farm laborers, as on- farm and non-farm wage laborers for others in agriculture and non-agriculture; as entrepreneurs, traders and providers of services [13]. Typically, rural women's roles and status in agriculture as well as their roles in non-farm activities and employment vary widely from region to region. Across regions, they are engaged in on- and nonfarm activities as Hill stipulated [14].

Hagglablade et al., also strengthen that women account for about one-quarter of the total full time rural non-farm employment workforce in most parts of the developing world [15]. Griffith cited in Gordon and Craig reminds us, the majority of the poor in sub-Saharan Africa are women [6]. Therefore, they have greater need than most of the income that can be secure through involvement in the non-farm sector. However, women have long been constrained in the activity in which they are permitted or able to participate by tradition, religion or social mores. When entering into non-farm activity requires substantial investments, liquidity constraints will hamper household's heads with restricted assets to enter into these activities. The ability of households' heads to overcome these entry barriers depends on their capacity variables such as collateral requirements, market imperfections and differences in repayment capacity make credit constraints more severe for poor households than for a rich Davis et al., [16].

From different literature in relation to NFA the challenges and opportunities to participate in NFA was overlooked. The aforementioned studies focus on the roles, growth, determinants of NFA to economic growth and household income, and impacts of NFA. More importantly, the studies indicate so far were not included gender issues in non-farm livelihood diversification. It is because of this practical research gap that the researcher triggered to conduct a study on the issue to explore the challenges and opportunities of women in non-farm activities in rural areas are justified. Furthermore, no efforts or intervention has been taken to investigate the challenges and opportunities of women's involvement in non agricultural activities in the study area; more importantly focused on farming activities with little attention given to non-ag- ricultural activities by researchers and policy makers in the study area in particular and in Ethiopia in general.

\section{General Objective of the Study}

The general objective of this study was to investigate the challenges and opportunities of female headed and male headed households in non-agricultural livelihood diversification strategies in Shebel Berenta Woreda, East Gojjam Zone, Amhara National Regional State.

Based on the general objective, the specific objectives of this study attempted to:

- $\quad$ Explore the challenges of female headed and male headed households to participate in non- agricultural livelihood diversification activities in the study area.

- Investigate the opportunities for female headed and male headed households to participate in non-agricultural livelihood diversification activities in the study area.

\section{Research Questions}

- What are the challenges of female headed households and male headed households to participate in non-agricultuarl livelihood diversification activities in the study area?

- What are the opportunities for female headed households and male headed households to participate in non-agricultural diversification activities in the study area?

\section{Materials and Methods}

\section{Description of the Study Area}

Geographically, Shebel Berenta Woreda is one of the Woredas' located in East Gojjam Zone, situated in the North- central highlands of Ethiopia in the Amhara National Regional State. It is extending between $10^{\circ} 15^{\prime} \mathrm{N}$ to $10^{\circ} 30^{\prime} \mathrm{N}$ degrees latitude and between $38015^{\prime} \mathrm{E}$ to $38^{\circ} 27^{\prime}$ 'degrees of longitude [17]. It is found at a road distance of $293 \mathrm{~km} \mathrm{NE}$ of Addis Ababa, capital city of Ethiopia. Shebel Berenta woreda is bordered on the South-West by Dejjen woreda; on the North-West by Enemay woreda; on the north by Enarj Enawga woreda, and South and South- East by Abay River Gorge, which separates it from Oromia region. The major town of Shebel Berenta woreda is Yedwuha [18].

Shebel Berenta Woreda covers a total land area of 89,714 hectares (ha). Topographically, $8.45 \%$ of the woreda is mountainous, $43.47 \%$ plain and $48.08 \%$ is valley. Its altitude ranges from $1800 \mathrm{~m}-2150 \mathrm{~m}$ above sea level. Shebel Berenta woreda has two agro-ecological zones with $(72.3 \%)$ Kolla and Woyina- Dega $(27.7 \%)$. Based on land coverage, most part of the woreda are situated in the lowlands (Kolla) along the Abaye River Gorge, and are extremely depleted, deforested and eroded. Moreover, rainfall is highly seasonal in the woreda; vivid evidences and experiences indicated that almost $90 \%$ of the total annual rainfall received in the woreda elapses during summer only. The average annual rainfall ranges from $4000 \mathrm{~mm}$ to $1000 \mathrm{~mm}$ [19].

Shebel Berenta woreda is structured with 21 kebeles of which two are urban and 19 rural kebeles. The estimated total population of Shebel Berenta woreda is 129,156 of the total population of the woreda, which consists of 61,640 males and 67,516 females. Out 
of the total population of the woreda, 11,271 (4955 males and 6316 females) are urban dwellers and the remaining 117,885 (56,685 males and 61,200 females) persons reside in the rural areas of the woreda. The 32,589 rural households counted in this Woreda, out of which 22, 839 are male-headed households, and the rest 9,750 are female- headed households [19]. Agriculture is the mainstay of the district livelihood activities for rural residents, which is characterized by subsistence crop production, it is mainly dependent on rainfall, which is erratic in nature and dominantly traditional farming system resulted in low- crop yields [17]. The available study by Hugo Rami also indicated that in 2002, it was judged to be one of four chronically food- insecure Woredas' in this part of the Amhara Region, due to much of their farmland being extremely depleted, deforested and eroded [18]. Despite of this, the productive safety net program is still provided as preventive social protection. On the other hand, there is also the presence of non-farm activities, which is practiced by rural households; though still given to poor households. Trading, weaving, blacksmithing, carpentry, leatherwork and food for work are among non-farm activities in the rural kebeles of the woreda.

\section{Report Approach}

The researcher was employed qualitative research approach to investigate the challenges and opportunities of women in non-farm livelihood diversification from gender perspectives. Alternatively,a qualitative approach is one in which the researcher often makes knowledge claims based primarily on constructive perspectives (i.e the multiple meaning of individual experience meanings). The researcher collects open ended emerging data with the primary intent of developing themes from the data [20]. Qualitative research often seeks a depth of information and attempts to gain understanding and insight related to the meaning that individuals give to their experiences. Taking in to account this advantage; the researcher was employed qualitative method to attain the objectives via qualitatively.

\section{Report Design}

Among the different kinds of qualitative research design, the researcher has employed case study design to attain the objective. Principally, case studies enable in which the researcher explores in depth about the program, an events ,an activity, a processes, or one or more individuals .The cases(s) are bound by time and activity and researchers collect detailed information using a variety of data collections procedures over a sustained period of time [20]. Taking in to account this advantage, the researcher was employed case study research design to investigate the challenges and opportunities of women in non-farm livelihood diversification in case of Shebel Berenta Woreda.

\section{Sampling Techniques}

The rationale for the choice of Shebel Berenta Woreda for this study area is based on the 2007-2009 E.C woreda report, which stated the woreda has severe problems of low productivity of agriculture, food insecurity and continuous existence of drought and it also needs other ways to sustain the livelihood of rural households [21]. Thus, provide a clue that about NFA is used as the best alternative ways to recover from vulnerability and risks is opted. Principally, based on the observation and experience in the study area, there is a deep-rooted problem of ignoring women's non-farm work decisions so it needs to investigate the problems of women for further intervention.

In this study, the participants for in depth information were selected using purposive sampling for participants in interviewees and focus group discussion that had experiences in non-farm work and who work in regularly through the year. Therefore, the participants in focus group discussions were selected purposively in each agro- ecology in such a way because the researcher intended to hold one group discussion on each of the kebeles. Accordingly, 10 interviewees, seven key informants and 28 focus group discussants with four groups having eight members and six members in two groups were taken to get acquired results respectively. Similarly, purposive sampling was employed to select key informant interviewees: since it used to enable to select the individuals who know about the issues and specific expertise about the needed information. Hence, the key informant interviewees were from Technic, Vocational, Enterprises Development officials, Women and Children Affairs officials, Trade, Industry and Market Development officials, Local Administration officials from each selected kebeles of Shebel Berenta Woreda as a source of relevant data for this study.

\section{Data Sources}

The study used both primary and secondary sources to obtain necessary information for this study. Hence, primary sources include survey interviewees, key informants and focus group discussion participants. While, secondary sources such as books, journals and annual reports that relates with the research problem or direct relation to the study were included. In line with this, Kothari indicated that using secondary data that are collecting and analyze by someone else or to written sources enable to interpret or record primary data [22].

\section{Trustworthiness of the Study}

Trustworthiness is seen as the strength of qualitative research. As stipulated by Shenton, there are four strategies to ensure trustworthiness in qualitative research [23]. These are credibility, transferability, dependability and confirmability. It used to suggest determining whether the findings are accurate from the standpoint of the researcher, the participants and the readers of an account. In ensuring trustworthiness, the researcher has employed data triangulation for ensuring credibility, while the researcher has employed a rich and deep explanation to convey the finding by examining evidence from the sources and utilizes it to construct a reasonable explanation for themes, which has been provided by the researcher to ensure transferability. The other strategy was member checking and in this regard, the researcher met them again and briefs the result of study in accordance with the information they gave. After a thorough discussion with them, the researcher got their approval on what they said. However, the researcher also made a little amendment on the result part that did not get member approval. In addition, thick notes were taken during interviews, observation and discussions to consolidate the study finding.

\section{Data Analysis Techniques}

In qualitative research, the process of data collection, data analysis and report writing are not distinct steps in the process. They 
are interrelated and often go on simultaneously in a research project [24]. The researcher is engaged in data analysis process at the same time of data collection. For this study, the researcher used thematic data analysis. Thematic analysis is a widely used qualitative data analysis method. The data which was collected from in-depth interview and organized based on the objective of the study and analyzed through thematic analysis. Thematic analysis aims to identify themes within the data. It's analysis is more inductive than content analysis because the categories into which themes has been sorted are not decided prior to coding the data. These categories are 'induced' from the data. While the general issues that are interest was determined prior to the analysis, the specific nature of the categories and themes to be explored are not predetermined. Each objective has been themes that are thematize based on the ideas they have on the topic that are highly envisaged by the researcher. In its nature, qualitative data analysis primarily entails classifying things, persons and events and the properties which characterize them.

\section{Results and Discussion}

Challenges of Female headed and Male headed households towards Non-Agricultural Livelihood diversification Participation in the Study Area

There were different challenges women faced to pursue non-agricultural livelihood activities interviewees as key informants and focus group discussants verified. These are:- negative outlooks of the society (cultural myths) towards handicrafts, shortage of working capital and credit services, absence of local infrastructure, the absence of market demand and customers, the absence of institutional and government support, lack of skill development training, absence of technology and technological support, and laws and regulation towards NFLD in the study area.

\section{Negative Outlook of the Society (Cultural myths) To- wards Handicrafts \\ The study found out that negative outlook of the community to- wards handicrafts is the principal challenge that women's faced in pursuing non-farm activities especially in handicrafts. The pres- ence of an outdated outlook on this specific work negatively af- fected the working condition of women's who engaged in NFA. According to informants and participants in focus group discus- sion, the negative outlook and suspicious beliefs towards hand- icrafts lays a problem on the improvement of women handicraft workers and they put it first as the serious problem that encoun- tered women in pursuing non-farm activities in the study area.}

\section{Suspicious belief}

Concerning this issue, one of the key informants disclosed as follows:

......in our community, handicraft (pottery, blacksmithing, weaving, and leather-works) is considered as a work of a lower class society or a community that are considered as unique from the other in their identity or caste. Due to this outdated and suspicious beliefs towards handicrafts, those people who engaged in handicrafts gave nicknames called "evil eye"(Buddha),"eje Seri (blacksmith)", "Anteregna (blacksmith)" "devil receivers (Satanic attractions)". Consequently, the community ignores them and did not include in membership such as Iddir, Iqub, Mahber and other informal institutions. To your surprise, marriage is not arranged with them due to ancestry or genetics. The community says why we arrange marriage with them ancestry or her ancestors. In addition, due to "genetics" so many women were constrained from the involvement in this particular activity, those women who involved are socially isolated. Therefore, outdated outlook is a common problem in our community for those who involved in handicrafts and it is better to say that the serious problem in our community! (Key Informant, 7).

\section{Social Isolation and Insulting}

Social isolation is also one of the social challenges that women faced in non-farm activities in the study area.Vivid evidence provided by one of the focus group discussants who engaged in leatherwork and pottery work currently divulged that:

It is difficult to explain in a single word, we have experienced too much suspicious beliefs that discourage our functioning of jobs. For example, previously too much insulting, isolation, and chaos issues have occurred with the community through considering ours as an evil eye. Because of this reason, common insulting such as fakiwoch, (Fellows) : Eje Seri (Craftsmen) : Evil eye (Buddhists) : Deben Ansa (Debenansa) always exist throughout our work. I do not know when this problem is stop. Still, the community says, we are Teff producers (White producer), used this term to inferior our work or for the purpose of undermine our jobs. This means that our work is considered as silly because one farmer considers himself as wealthy if he engaged in agriculture or have a huge land rather than engaging in handicraft work. Hence, if the administrators will not take action, our lives continue to be in dangers, even it is difficult for our children safety (Interviewee, 2).

\section{Lack of Social Insecurity}

Lack of social insecurity is also another social challenge that women faced in non-farm activity participation in the study area. Many of handicraft workers faced social insecurity from the same community dwellers without any possible justification or with suspicious belief. In this regard, one of the informants gave emphasized and strengthen the point by saying:

When I tell you by emphasis and what you have to underline is that, those handicraft workers faced social insecurity in our kebele. This is because in the areas, there are some bad individuals who make chaos, fear them and hit their house at night time to leave them from the dweller. Having this fear of insulting, social isolation, and social insecurity from the community, so many rural dweller's including women constrained from involvement even if they have the skills, and those involved has also in severe situations in handicrafts at all!. Ironically, their inhabitant is separated from the other community. There specific dwelling place or Got called "Tach Amba". The name given to this place by the community is that, to indicate the site of pottery workers, blacksmith workers, and weavers as well. To address this problem, I was telling so many times in different community dialogue. However, no improvement is attained on the mindset of the community to alleviate their bad traditional norm and experiences (Key Informant, 5). 
As per the result of the above explanation, we can infer that the outlook of the society towards non-farm activities negatively affected the involvement of women in non-farm activities. This means that, negative outlooks of a given community towards a particular non-farm activity both constrained them and challenge for women's in non-farm participation. This poses a problem for many women in rural areas that were not left out from poverty, food insecurity and unemployment as key informants verified. This result is in agreement with the works of Tesfaye, which indicates that artisans are marginalized in the society where weavers and basket makers are usually disposed terms by the society although their activities are highly essential to livelihood security of the society [25]. The study also reported that the social problem (25.4\%) of sample households pursuing RNFA is straining social outlook. In similar fashion, Yona and Mathewos also found out that, the attitude of the society towards artisans' professionals is not as such supportive [26]. They consider them as minorities and caste while using all the products produced by the professionals. This implied that further efforts would make to alleviate problem to enable women's to be active participant in non-farm activities.

\section{Absence of Institutional and Government Supports}

The finding of this research also revealed that the absence of support from the government and institution is the secondary challenges that women faced in pursuing NFA despite the fact that so many women's in rural areas faced the challenges of lack of advisory services, workplace problems and raw materials for their nonfarm work. We know that, the provision of government supports in terms of giving working place for non-farm workers, advisory services and providing inputs/tools is the prerequisite for non-farm business development; but still the institutional or governmental support towards the sector is limited as key informants pointed out. In line with this, focus group discussants also verified that, they faced the problem of working place, especially in non-farm self-employment (trade, grain milling services and vegetable and fruit selling) due to the absence of government and institutional support.

\section{Absence of Monitoring Support}

The absence of monitoring support is one of the institutional challenges that women faced on non-farm activities in the study area. This poses to the inability of accomplishing their non-farm income generating activities effectively as they expected and work without income increment.

One of the interviewee shared her experience in the following manner:

I have been working for more than 9 years in leather works (i.e. Agelgl-melegom, Dirb-Melogom, Ankelba- mesrat, Jendimalesles). But still I did not have taken any monitoring support from the government side. No one came to me to know how my work is going and in what ways my work is effectively accomplished. When I tell you without exaggeration no responsible organs is found in our Kebele that gives assistance to this kind of work. This limits my moral motivation. Even nowadays, I want to stop this work because no improvement is achieved in both my work style and benefits as much as required rather than exerting a huge effort to day-to-day consumption or hand-to -mouth just due to the absence of support (interviewee, 8).

One of the informants also supplemented the above ideas through deemed that:

Frankly speaking, we did not provide any monitoring support for handicrafts because this activity did not facilitate economic transactions. Hence, to facilitate an economic transaction, we focused only on modern handicraft jobs. Having this case, still the provision of raw materials and working place is not trended and adopted by our offices to rural women in non-farm participation rather than approved trade licenses only (Focus Group Discussant, 3 ).

\section{Lack of Proper Workplace and Raw materials}

Lack of working place is also another major challenge that women faced in non-farm activity participation in the study area. The data from participants in focus group discussion and informants revealed that, there is no proper working place to run their nonfarm business. One thing that this study reminds that, this problem is serious for women traders, seller of local drinks who work in cooperative and vegetable sellers in the nearest town on formal ways. In this regard, one of the participants in the interview disclosed that:

I have one small container for retail shopping nearest to the main road. Nevertheless, I undertake grain trade regularly on formal way in the nearest town (Yedwuha). My working place for trade is looks like fire proof: it is very small. Having this case, it is very cumbersome for me to work while I bought more than two Quintiles. Therefore, to cope with this, I began to buy in roadsides from rural dwellers (Interviewee, 10).

One of the key informants also supported the above ideas as follows:

.......it is unquestionable; pursuing NFA is inadequate without working place, raw materials and access to equipment's machinery. In this regard, only five containers were provided for those who engaged in trade, food processing and sale of local drinks who worked in cooperatives in 2010 budget year. However, the problems still exist due to budget deficits and lack of special emphasis to the sector. For example, due to the absence of special attention to the sector, handicraft activity is not supported by expertise and did not have a package at college level. Thus, to alleviate this problem, nowadays administrative solution or an effort is provided for both urban and rural kebele administrations since the direction is forwarded to those women who are willing to cooperate in temporary for 5 years with signed agreement (Key Informant, 1).

As per the result of the study indicated, one can deduce that due to the absence of institutional support for non-farm activity participation lays a working place and raw materials challenge for women in NFA work decisions. This result is consistent with that of Mehta study, which indicates that most sufferers in terms of the working place, and accessibility to raw material and those are covering a longer distances for getting required raw materials are visualized among the traditional household rural industrial enterprises [27]. In similar vein, the study of Varsha stipulated that the higher cost is one of the rural industry's problems and they tackle the problem of rising costs of raw materials for example the steel and textile 
industries based on iron and cotton shortfalls of raw materials [28]. Similarly, the study conducted by FAO showed that, women's limited access to support, working place and control over equipment and transportation constrains their income earning opportunities and their access to markets [29].

However, in grievance of this study finding, Kazungu and Tang finds out that in Uganda, institutions underlying the development of rural non-farm sector very strong [30]. Here again in grievance, the study of Richard showed that the handicraft is a home-based industry, which requires minimum expenditure and infrastructure to establish [31]. The study further elaborated that; it can create jobs at a minimal cost. In general, this sector uses existing skills, locally available raw materials inputs required can easily be provided, and product adaptation is less expensive than investing in energy, machinery or technology.

\section{Shortage of Working Capital and Credit Services}

The study found out that, lack of working capital and credit is the major bottleneck for women in non-farm activity participation due to the absence of credit services from the institutions and their poor economic backgrounds of most rural dwellers in the study area. In this regard, one of the interviewee narrated the challenge as follows:

Our major bottleneck while undertaking non-farm activity (selling of vegetable, fruits, sale of local drinks with cooperative and trade) is the shortage of working capital. This is due to limited income in our household and the absence of credit. Even if while asking to take credit, the loaning procedure is difficult. We stayed more than one month to take a loan, their voluntariness also not as much enough and encouraging. To obtain credit, we have no guarantee or collateral. Because of this, we take "Dubie and Arata" from relatives. However, occasionally we use livestock as collateral to take a loan. But, the basic thing is that, it is not only the lack of collateral rather the problem of mal-administration to take credit because the institutions of credit give loan to those wealthy individuals selectively. In addition to this, obtaining credit in a short time is unthinkable. Although, ACSI is the major credit source; institutions always accessed for those who have collateral. This is not fair, why not free loan is provided for poor? (Interviewee, 4).

In contrast, one explanation from the words of one key informant deduced that:

The serious problem of women is that, the absence of voluntariness to take credit in collaboration with other women while working NFA. Above all, formal financial institutions like banks, credit and saving institutions did not give credit to those women because they did not have collateral and some of their activities in non-farm did not have guarantee (for example sale of firewood, pottery, sale of local drinks without cooperative) (Key Informant, 2).

Therefore, the result implied that, the absence of working capital and credit is a serious problem that strongly hinders the monthly income of women's in non-farm activity participation. In line with this result, Varsha pointed out that the availability of finance, credit is not easy to rural people, and they always face challenges on the scarcity of finance and credit [28]. The capital base of the small industries in this context is worse. The Author further elaborat- ed that the rural artisans are running small industries or cottage industries either on little capital they possess or take credit from indigenous bankers or on the traders who supply raw materials to them. In many cases, such credit is obtained at a very high rate of interest and it is exploitative in character due to that there has increased production cost of the artisans. Likewise, Dilruba and Roy also pointed out that, poor asset base and lack of credit services is the most important constraint to livelihood diversification; possession of even a small asset enables the households to take opportunities in the non-farm sector, particularly in the self-employment sector [32]. Consistent with this study finding, the study of Mori also reveals that limited access to relevant and affordable services, such loan levels suited to business needs, technical and management training, advice and marketing, locating a suitable premise constrain women entrepreneurs [33]. One key constraint for women is their unequal possession of the collateral needed to obtain credit. Women's collateral levels are lower than those of men because they are generally poorer than men, paid less for their labor time and own fewer assets as reported by FAO (2011b) cited in Inter-American Development Bank [34].

\section{Absence of Local Infrastructure}

The study found out that, the absence of local infrastructure is the major bottleneck for women in non-farm participation in the study area. Even though, the term infrastructure is the double edge word, in addition to the researcher observation, the informants and participants in focus group discussion verified that a significant number of rural dwellers had not accessed basic rural infrastructure, mainly water supply, electricity, road and market accessibility to non-farm work. This lays the problems not only for non-farm workers, but also it diminished the agricultural productivity and non-farm business development. In addition to this, according to key informants and participants in focus group discussion, in rural kebeles the accessibility of transport services and telecommunication had not accessed to undertake rural non-farm activities in the study area.

\section{Absence of Rural Electricity}

The study found out that, the absence of electricity is as one of infrastructural challenges for women in non-farm work in the study area. The absence of electricity negatively affected the improvement of non-farm business development in rural areas. Likewise, women's in the study area were faced the absence of electricity and lays to work burden and increase their time poverty as discussants verified. In correspond to the above point; one of the FGD participants disclosed that:

We started with 5 members to sell tea, tella and areqi and processing foods before 1 year in the farmers' association or unions in Gebsit kebele, it is really good in our income. However, the absence of electricity discouraged our work because we still pursue our activities using firewood and charcoal. This makes busy, time consuming and complex in our work. Nevertheless, if there is accessibility of electricity, we will open additional tea room service and leave from firewood collection for fuel consumption (Focus Group Discussant, 4).

\section{Lack Road and Public Transport services}

The other most severe handicap to their non-farm business par- 
ticipation identified by informants and discussants is road, water supply and public transport. The problem is more acute in both kebeles as no road network and water supply is available there. Lack of public transport services and telecommunication is the second infrastructural handicap identified by participants in focus group discussion that constrain their improvement in enterprise-based diversification in the selected kebeles of the study area. In this connection, one of the interviewee shared her experiences by saying: Nowadays I am working both sale of vegetable, firewood and charcoal production. I gather both firewood and charcoal from the Abay River Gorge. Then I always sell it to the market by walking more than two and half hours to reach to the main market. It is very cumbersome to travel a long distance of road. It is not comfortable for me. It is top and down structure to reach from Kolla up to Woyina Dega. To cope this long distance and top down structure of road, one day I was sitting more than three places to reduce my fatigue. Then after, I reached at 6 hour after I started the journey before 3 hour from my house. This is bulky and tire for my work (interviewee, 9).

One of the key informants also supplemented the above narration and deemed that:

It is needless to say that, good infrastructure has play an important role in facilitating rural communities to pursuing income generating activities, but the accessibility of rural road and transport services had not yet been provided. It is difficult to see women diversify into non-farm enterprises and generate income to sustain their livelihoods. In fact, there is a strong case for arguing that public infrastructure (road, bridge, electricity, public transport services) are the major problems of Shebel Berenta woreda due to undulating topography prevailing in the area (Key Informant, 2).

From the above narration, one can deduce that due to the absence of road network and transport services, so many of rural women travel a long distance to pursue NFA. This hinders the active involvement of women and lays to tiresome and inability to pursuing their non-farm work easily. The result implied that, women require accessibility of road and public transport services for non- farm work to improve in their income, reduce tiredness and time consumption.

\section{Lack Rural Water Supply and Telecommunication}

The absence of rural water supply and telecommunication is also another major infrastructural challenge for women to non-farm work in the study area. The absence of rural water supply negatively affected the improvement of non-farm business development in rural areas. Likewise, women's in the study area faced with the absence of water supply and telecommunication and this lies to conflict, work burden and increase their time poverty as discussants verified.

Correspondingly, one of the key informants of this study also stressed that:

Especially, manufacturing and service sector by its nature require electricity, water supply and telecommunication. However, even though they are willing to involve and are involved, due to the absence of commitment from higher concerned bodies to solve this infrastructural problem: still the problem exists and concerning the infrastructure, immediate solution is not provided. I do not know why the government did not provide immediate solutions. Therefore, what the higher concerned bodies have to take into account is that, there are no infrastructure is found in small towns and rural kebeles that encourage women's participation in NFA. To this end, the limitation of poor infrastructure places far behind in their non-farm business development in the livelihood strategies of rural dwellers (Key Informant, 1).

From this result, we can grasp that the major problem in pursuing a high level of rural non-farm activity in the study area is the lack of infrastructure (mainly electricity \& telecommunication and public transport in addition with rural water supply and road). This result is in agreement with the works of Shamy, which indicates that poor transport and road services affect much those entrepreneurs who engaged in the timber industry [35]. The road infrastructures from the timber production areas of the village center, which is the timber market centers, are not conducive for the transportation of timbers. The study further elaborated that the roads are seasonal which to some extent increases the timbers production cost. Timber producers are also affected by the access to electricity because the electricity is not accessible to timber production areas.

Here again, this result is in agreement with the works of MAAIF cited in Kazungu and Tang, which indicates that the most significant bottleneck in generating higher levels of rural non-farm activity in Uganda is the quantity, quality and reliability of the infrastructure [30]. Regional physical infrastructure as well remains a challenge for especially boosting regional trade in particular and non-farm activity in general. In similar manner, Yona and Mathewos. Hussein and Nelson. Dilruba and Roy studies also illustrated that due to lack of basic infrastructure like electricity, telecommunication, road network, transport and water supply, rural households have little or no opportunity in the non-farm sector to expand livelihood choices $[7,26,32]$. As a result, virtually no scope exists for the rural households to diversify their livelihood.

\section{Limited Market Demand and Absence of Customer}

This study found out that, limited market demand and absence of customers is the basic challenges that women faced while pursuing NFA in the study area. The data from interview and focus group discussion revealed that unlike other farm products, non- farm activity especially clay products, and local drinks and processed foods had limited market demand and absence of customers in the study area. According to the discussants and informants, in addition to inaccessibility of a market for clay products, lack of market demand for most non-farm products is the major inhibitors for women in income generating activities.

In this regard, one of the interviewee divulged that:

When I am working on pottery for more than 7 years, my product is quite attractive. However, the local community did not buy my products since most of rural farm household experience and the habit of consuming clay products is diminished after some years. In line with this, I made a single poet with huge efforts and high quality, but I sold with minimum local price or coin. Therefore, when we compare my efforts to produce this clay product and coin, it has a huge difference. To tell the truth, even though our products are valuable role; the market demand is limited after steel products come into the market for rural dwellers. Because of this, even 
though there are large numbers of mothers and girls were involved in pottery; our outputs and clay products (i.e. Mitad, Masero, Gan, and Dst) are not adequately demanded and exchanged by the local community as much as required. Hence, regarding the local community market demand and exchange towards consuming our products and outputs are limited in the majority of rural areas (interviewee, 6).

From the above explanation, it can be possible to conclude that limited market demand and accessibility of market is the major problems for women's to pursuing NFA. Corroborate with this study finding, Mehta study shows that lack of demand for the products of rural industrial enterprises outside local and rural areas is often considered as a serious constraint in non-farm expansion and development [27]. Large proportions of items produced by household-based traditional rural industrial units are utilitarian rather than luxury goods. The study further elaborated that, the blacksmiths, rope making, flour-mills, woolen and servicing and repairing units are unlikely making any plan for the expansion of their units due to inadequately developed marketing arrangements and linkages for selling their goods and articles outside rural areas. In line with this result, FAO, IFAD and ILO also pointed out that non-traditional agricultural exports offers an opportunity for generating quality employment for rural women and men, but there are also risks, especially for women, who are often the weakest nodes in the supply value chain in Latin America. However, the result is inconsistent with the work of Gesesse and Ignatious, which indicates that Mitad [a large pan for baking the Ethiopian flat cake, injera] holds better demand and was sold for better prices than any other clay products in NFA [36].

\section{Lack of Skill Development Non-farm Training}

The study found out that, absence of skill-based training is the other major challenges for women in their non-farm business. The general importance of training for non-farm income generating activity is clear. Those with high skills and training levels are more often participate in all types of non-farm activities. Plausibly, because short-term training better reward people to generate a sense of confidence and enabling individuals to involve themselves in non-farm activities; having training on non-farm activities still unavailable as key informants and FGD participants verified. In this connection, one of the interviewee stated her experiences by saying:

I have completed grade 8 before Ehadig (EPRDF) come into power. Due to limited productivity of my cultivated land, now a day I am working embroidery and spinning regularly for more than three years. However, until today I had not received any training from government officials. Even when we are asking in-group to get land and additional skill in our kebele and woreda administration, the administrators are not responsible to responding our questions rather than preferring silence. I do not know the reason behind. Having this rationale, I still work without improvement in both salary and skill. Therefore, the absence of training makes me limited on both my jobs improvement and ability to acquire a better salary from my work. Because, I am still working embroidery (i.e Netela and Gabi), what I have worked with similar knowledge as previous or the year before year! (Interviewee, 5).
By supporting the above narration, one of the key informant interviewee also deemed that:

Still, our office did not provide skill development training towards non-farm activities, especially in artisans activities because it is still unrecognized. The government did not know this particular activity as the major income generating activity for women. Having this little attention, no expert is recruited to support this particular activity. This institutional problem manifests itself through the absence of consultation and advisory services and to the most part, the absence of a clearly defined institutional framework to assist the NFA. Despite the fact that, many of women had faced the difficulty to adopt working environment in NFA participation since they were not oriented about the work and the whole environment as well (Key Informant, 2).

On the other hand, one of the informants of this study unanimously rejects the view of the above informants and FGD participants by saying:

Our office, still provide awareness creation or training in manufacturing and services sectors for women regarding how to deliver the service. However, the very serious problem is that women's awareness is unincorporated to take training and pursuing non-agricultural livelihood activities due to illiteracy. Having taken into account several efforts would make for the future by arranging discussion with smallholder's farmers in all rural areas about non-farm activity (Key Informant, 1).

This result is inconsistent with the works of Gordon and Craig, which shows that vocational training in small business development projects regularly offers a range of services including education in business skills [6]. Their study also illustrated that vocational training in traditional trades (baking, brick making, building skills, handicrafts, and workshop repairs) also offered at specialized colleges, or sometimes as part of the school curriculum. Some organizations run short courses targeted to local needs. However, corroborate with this study finding, Shamy pointed out that factors include lack of specific skills and inadequate entrepreneurship skills in some non-farm activities such as tailoring, carpentry, welding and garage (vehicle and motorcycle repairs) is attributed much by the absence of vocational training school and the absence of training institution that provides business skills in the surveyed village (Tanzania) [35].

Absence of Technology and Technological Supports

The other challenge identified by the participants of this study is the absence of technology and technological assistance for their non-farm work. In a sense that the assisted modern equipment that facilitates the active engagement and improvement in their work is not provided by the institutions as well as they had not any modern equipment to accelerate their non-farm work; still they practiced through traditionally with existing hand tools and experiences. According to participants in focus group discussion, the absence of assisted technological equipment was hampering their participation in diversified non-farm income generating activities: the assisted technological support is still unavailable to facilitate their non-farm participation. In this regard, one of the informant interviewee deduced that: 
........ for example handicrafts activity still undertaken on similar ways or condition, which was undertaken before 100 years situation without any assisted technology. Because of this, women did not produce required output in which the community needed or preferred. Though their output is produced, it is not competitive products. Consequently, the community prefers to leave their outputs since they assume that their products are low quality. Therefore, assisting all activities in non-farm for women to improve their participation and benefit from the sector in the government side still unthinkable. In this regard, technical and vocational colleges in particular and the government in general should take into account since it is the major challenges for women in non-farm participation (Key Informant, 3).

Correspondingly, vivid evidence provided by one of the interviewee divulged that:

Nowadays without exaggerating, we can say that we all women's still undertake and practice weaving, pottery, sale of local drinks and food processing via traditionally (i.e hand):"We are working by hand". Due to this reason, while I went to Yedwuha Clinic, the doctor said you were TB victim. Asking the doctor by shocking what is the cause of this, he said a huge amount of smoke affected your lungs. Then I also perceive this, the cause exists while I make pottery (i.e Gan, Dist, Masero, Mitad) and sometimes while I produce charcoal. Nevertheless, nowadays I am working with a health problem because I do not have any other means of getting birr. If I stop working, my children do not have food for hand to mouth. Therefore, the government should say one thing for ours to be an active producer of quality product to market, to our health condition and to obtain a good income for food for our children! (Interviewee, 4).

As per the result of the study, one can deduce that, the absence of technology hinders the good function of women in non-farm participation in the study area. This result implied that, technological support is not the only prerequisite for agricultural activities rather it is also perquisite to NFA participation. Hence, due to the absence of technology and technological support so many women lay on health problems, hindering the active involvement in NFA easily and improvement of in their work as key informants and FGD participants verified. Corroborate with this study finding, Gesesse and Ignatious they pointed out that non-farm activities had not received any form of technological support [36]. The production was still carried out traditionally and the work remained tiring. Here again, in agreement with this study finding, Tezera study also indicates that backward technology and competition of manufactured products has undermined the growth and development of non-farm activities [37]. In similar manner, mounting evidence provided by UNID; FAO, IFAD, ILO; UNDP cited in Ojulu also explained that the SME sector is all too often marked by outdated and inefficient practices and technologies [38,39]. As a result, small enterprises tend to operate far below their productive capacity. The study further elaborated that small-scale businesses often used inefficient low-cost technologies, which yield products of poor quality and pose hazards to health and the environment due to the inability to afford adequate tools and machinery necessary to produce goods competitive in quality and prices.

\section{Laws and Regulations Towards NFA}

In accordance with the finding of the study, the existing laws and regulation is one of the challenges that affect the involvement of women in non-farm activities. The regulation of small-scale sector constitutes an important aspect of non-farm development; however, the bureaucracy affects rural non-farm business development. This is because the current polices prohibited some activities in non-farm; rural dwellers constrained from involvement in NFA participation. In this regard, one of the informants deduced as follows:

As you know, the current government prohibited the roadside trade, sale of firewood and charcoal production to prevent soil deterioration and conservation. Due to this reason, the local residents have been constrained from undertaking trade in the roadside trade, charcoal production and sale of firewood since most of the people involved in the production of charcoal by cutting forests and roadside trade without a license. However, rural dwellers, including women still practiced illegally. This leads to punishment and arrest for those who involved in firewood and charcoal sellers and non-license traders. Because, they are against rules and laws. So, it is the major challenge for charcoal and firewood sellers as well as traders who work without licenses in roadside. In addition to this, the government lays tax deliberately without checking cost benefit analysis for women who work in a legal way. Due to this, women traders leave and force to leave from the trade due to improper tax regulation in addition to license approval problem (Key Informant, 7).

In this connection, one of the interviewee also supported the above ideas as follows:

Our major problem in charcoal sales is the prohibition of the government. This lay down fear of punishment and hesitating to actively involving in firewood and charcoal. In addition to this, we fear to registering our business, for example: roadside trades because of their cumbersome regulation and licensing procedures. We know those registered their business, the process was really cumbersome! (Interviewee, 1).

In support of the above narrations, the informants of this study also remarked that:

Even if non-farm activities have so many valuable roles, encouraging this non-farm activity (i.e. sale of local drinks, sale of firewood and charcoal, pottery) on government side still far behind. As well, nowadays, encouraging women to become active participant and to be more beneficial in the legal way in the most NFA still far behind and needs further efforts from the government! (Key Informant, 3).

From the result, we can grasp that the licensing procedures were not suitable for women in non-farm enterprise. Hence, the result implied that restriction on some activities in non- farm and the long process of licensing procedures challenge for women towards NFA participation. Likewise, from the above result, it can be possible to say and understand that, the government biased towards the agricultural sector, while non-farm sector operators have not received the required support from government bodies; still the majority of NFA did not provide policy attention rather than agriculture. This result is in agreement with the work of Mehta, which indicates that due to the variety of restrictions imposed by the government against the deforestation to avoid the various adverse 
consequences of environmental degradations as experienced in the past [27]. The general price level of different forest products in general and timbers in particular has unprecentedly been increased in the non-farm sector in the state (India).

In similar manner, regulatory restrictions on small-scale sector do not allow easy formation and registration of Small and medium enterprises in Uganda. This bureaucracy has affected rural nonfarm growth [30]. Likewise, Sinidu cited in Tezera indicated that the absence of policies is found to be the major problems of NFA [37]. Ana and Demmelash study also indicated that due to a government program to protect forest and environment balance almost all households being out of charcoal production excluding $4.7 \%$ household whom depend on this occupation as primarily in the non-farm sector [40].

\section{Opportunities of Women's towards NFA Participation in the Study Area}

\section{Presence of Family Support}

Despite the above pinpointed challenges, which affect their fair participation in non-farm, there are also a few opportunities, which can help them to improve their non-farm business. So, the existing opportunities were discussed based on the data obtained from participants as follows. In this regard, even though women in nonfarm activity encountered a dozen of challenges, there is also an opportunity for them to actively participate in non-farm activities. According to focus group discussion participants and informants, the presence of family support in their engagement in non-farm work is supportive for their non-farm income or salary accumulation and day-to-day consumption for family welling as well as for food security. This indicated that a family supports for women's to become an active participant in non-farm activities is supportive as FGD participants verified. In this regard, one of the interviewee shared her experience as follows:

Frankly speaking, I have received assistance from many directions while pursuing my non-farm work. Nevertheless, the cornerstone for my work continuity and improvement is the presence of family support without negligence. Due to this, I have been working trade regularly for five consecutive years. Even if previously when I was sick for 4 months, I decided to stop until I returned to my normal health condition. However, due to the continuous encouragement of my aunts, my uncles, my husband and my husband's families, my health conditions become well and I am continuing my own nonfarm work (trade) again. This is my pleasure for me. God bless all (interviewee, 7).

In corresponding, one of the key informants of this study also pointed out that:

In rural communities, family members can help each other in order to encourage their economic well-being and is usually working in cooperation, especially after agricultural activities completed from February (Meher season). This is because after being engaged, those family members expect higher salaries from their engagement. Having this reason, support also continued throughout their work. Therefore, we can say that mutual support among family members is strong in our kebele (Key Informant, 6).

In support of the above narrations, one of the informants also dis- closed that:

Telling to those families who have five or six family members to cooperate and start up any of non-work as they want. Then, families become voluntary to take capital by giving their green books of land for collateral. This is because they become voluntary for children to be economically independent from them. Therefore, families can volunteer to be guarantor for their girls and boys. What I want to underline at this point is that, the family has provided support to their children from their pocket even if the institution did not access to credit for women: most of family ask and want to sign their signature to be a guarantor for women and girls to credit. So, I can say that, it is well cooperative to each other in rural dwellers (Key Informant, 5).

As per the finding of the study, we can grasp that the presence of family support is an important opportunity to women's for fair participation in NFA in the study area. This result is in agreement with the work of Gesese and Ignatious, which indicates that family members help with each other in ancillary aspects of some activities such as fanning traditional furnace in iron-works, spinning thread into strands during weaving or loading and unloading donkeys [36]. However, inconsistent with this result, Ana and Demmelash study reveals that decline of family mutual support as one of non-farm livelihood challenges [40]. Nirmala study also pointed out that many times their own family members are not supporting and cooperating [41]. The study further elaborated that they are always making many pessimistic feelings to be aroused in their minds and making them feel that family and not business is a place meant for them. Due to such limited scope of help and cooperation from family and other people, they drop the idea of excelling in the enterprise field.

\section{Availability of Natural Resources (Forests and their own Eucalyptus trees)}

Concerning this case, the informants deduced that:

Although forest is available, it is impossible to use it for sale of charcoal and firewood. However, it can be used for the purpose of their own home use, such as use for preparing local drinks and processing of foods except for charcoal selling. This is due to the prevention of increment of deforestation undertaken by local people to sell charcoal and firewood; but still it has not protected well (Key Informant, 5).

The other important thing is that, the availability of red basaltic soils in the lowland parts of the study area (Karma and Aba Selmana Daboch Kebeles) which is used as an important opportunity for women to pursuing NFA (example pottery such as Masero, Mitad, Gan, Dst and other clay products) as FGD participants verified. From the result, it can deduce that, the availability of natural capital such as natural resources for women had an important opportunity for their non-farm activity participation. In line with this result, Mehta indicates that most raw materials were locally and easily available in adequate quantity at reasonable prices and obtained from the local forests without paying any cost of it [27]. Most of the forest products can be obtained through making at least some amount of payments for its collection in the form of royalty to the forest department and the Van Panchayats (India). In similar manner, Tesfaye pointed out that the presence of forest products such 
as Bamboo trees (used for making baskets), and other woody trees (mainly eucalyptus tree) is an important opportunity for pursuing RNFA [25].

\section{Presence of Support in Business Plan Preparations and Management}

The data collected from participants showed that, women have an opportunity regarding obtaining business plan preparation and business management support in some cases. According to informants and focus group discussants, the presence of business plan preparation and business management training from the institution is supportive and encourageable for the future. Having this opportunity, women who work in cooperative (e g. sale of drinks and tea room services) leave from business risks as focus group discussion participants verified. Correspond with this idea, key informant interviewee pointed out that:

Business plan preparation is continues work of our office for women concerning about how to attract customers, how to save money from their work and what kinds of work is appropriate for each woman based on their ability. This increases their involvement in non-farm income generating activities from the year up to year (Key Informant, 1).

In this connection, one of the interviewee confirmed the above idea as follows:

After licenses approval, our office provides business plans and business management awareness for women to work in accordance with those licenses permission required and approved. In addition, this service provided to hinder them from business loss or risk and to properly manage their non-farm business in their work throughout their involvement; even though there is continuous monitoring and service delivery training still we have a limitation in our offices to rural areas (interviewee, 3 ).

In supporting the above narration, one of the interview participants disclosed that:

Our main source of credit institution is ACSI, primarily the cooperation or arrangement is made with three up to four individuals. Then, the saving institution experts give training about how to use money and for what purpose we could use it since they told every aspect of business management. Then we take money and use for non-farm activity and farm activities. Therefore, taking this support is a share of our role to preventing risk and to using the money to allocate tasks efficiently, pave the way for our work, and initiate to start up other jobs in non-farm activity (Focus Group Discussant, 2).

From the result, we can conclude that the availability of business plan preparation and business management is an important opportunity for women to be active participant in their non-farm work. This result implied that, obtaining business management support and training play a significant role in non-farm activity participation for women in rural areas. Corroborate with this result, SARDP showed that business plan preparation enables the provider helped the client prepare a business plan, giving details about the enterprises and its intended non-farm activities [42]. In similar vein, Mori study also shows that access to business development services (BDS) is crucial for the success of WOEs to strengthen their capacity to start, effectively manage and grow their business [33]. The Authoress further elaborated that although there are many organizations providing business development services (including training, counseling and consultancy in the areas of business planning, legal, accounting, auditing, etc.) they typically serve only a very small number of formal MSMEs. Few women entrepreneurs access these services and few business development service providers specifically target women.

\section{Presence of Mutual Support in their own Association}

The other important thing that the study founds out is that the presence of mutual support of women in their own association while pursuing non-farm activities in the study area. The presence of mutual support in their own association helps women to facilitate their active involvement in their non-farm work participation and productivity. In this regard, one of the focus group discussants also affirmed the above idea by saying:

Even though some women's were the members of our association, we were able to help each other in sharing our experiences, information and mutual saving in pursuing NFA. Still, our association belongs to ours to encourage our members' participation and income improvement in our work. Having this mutual trust, it paves a way to participate in different meeting and dialogue as a role model (Focus Group Discussion, 1).

Regarding this, one of the key informants of this study also deduced that:

The main aim of our office is to encourage the participation of women and their beneficiaries in all economic, social and political spheres of life via participating in different economic activities. Therefore, to conduct this, several women arrangements or association are formed and used. Accordingly, in budget year-2010, women become involved in food processing and tea rooms in the trade sector through cooperation in different rural kebeles. This is vital for women to work in common purpose, share their experiences and to become role models for other women in non-farm work decision (Key Informant, 4).

Based on the above narration, we can deduce that the presence of mutual trust in their own association is supportive for women in the overall non-farm improvement and participation, as well as strengthen their social capital (i.e. social network, affiliation, membership, information sharing, being a role model and have visionary woman) in non-farm business development in rural areas in particular and for rural transformations in general.

This result is consistent with the works of $\mathrm{UN}(2008)$, which indicates that belonging to a network is a key strategy to acquire role models, increase business contacts, market opportunities and further develop their product or service. Business and sector membership associations play a major role in advocating for the needs of the non-farm business community in public-private sphere. In similar vein, the study of International Financial Corporation also pointed out that, the presence of women-focused associations, mutual trust and networks is very important for women to air their views [43]. However, in grievance of this study finding, FAO, IFAD and ILO study indicates that gender mixed cooperatives have often been unsuccessful and women-only cooperatives 
sometimes suffer from their exclusion of men, which can result in resistance to their initiatives and impede changes in existing gender relations in society. In sum, those few light that is used as an important opportunity to women's for fair participation in nonfarm activities is existed in the study area. It should be supportive in the long- run for women to be an active participant in livelihood diversification towards non-farm activity participation to attain food security, address low productivity of agriculture, increment of income for family wellbeing, eradicating gender inequality and reducing poverty in rural areas at all.

\section{Conclusion and Recommendations Conclusion}

The finding of the study illustrated that women's were faced so many challenges towards non-farm activity participation in the study area. These are: negative outlooks of the society, the absence of institutional and government support, lack of skill development training, shortage of working capital and credit services, absence of local infrastructure such as electricity, transportation, road, water supply, market inaccessibility, and limited market demand and customers, absence of technology and technological support, and laws and regulation towards NFA. Finally, the study revealed that women were also the available opportunity to have an active participant in non-farm work such as the presence of family support, the accessibility of natural resources, presence of business plan preparation and business management and the presence of mutual support in their own association. To enable rural women to be active participant and benefited from non-farm sector, using those existing opportunities and such the aforementioned challenges can be reduce through the help of government and non-government organization is vital $[44,45]$.

\section{Recommendations}

Based on the finding of the study the following points were forwarded for the concerned bodies.

1. The government and institutions should provide appropriate support for the non-farm activity this is due to the fact that many of women in non-farm activity participation in rural areas did not get appropriate institutional and government support and they faced the problems of working place, raw materials and technology. Not only supporting the sector, it also should provide special assistance for women to be active participant in the sector and to be economically empowered, to reduce time poverty, and to avoid gender biased in the sector through translation the policy intention into action via mainstreaming non-farm sector and integration with farm sector.

2. The administrative officials and experts should provide awareness creation and adequate training for women about how to pursue non-farm income generating activities; not only for women, but also to all rural dweller's about non-farm income diversification since it has an impact on women's participation in NFA. The rural dwellers did not assume that activity is not found outside agriculture: having this, the outlook of the society towards handicrafts is negative. Hence, awareness creation and training also needed to negative outlooks and cultural myths, which assumed that handicrafts are works of lower class society and are not belong to men work only.

3. The governments have to adequately address the problems of local physical infrastructure, mainly electricity, road, water supply, market, public transport and telecommunication not only to women in non-farm participation but also to farming productivity as well. Since, lacks of infrastructure accessibility are the obstacle to women's participation in non-farm activity. In addition, locally preferable infrastructure should be built in accordance with the voices of the rural community in general and women's in particular for non-farm livelihood diversification and farm productivity.

4. Saving and credit institutions and expertise have to provide adequate credit services with minimum interest rate for a long period of time, expanding branches to easily access to all rural dwellers, with a simple procedure and free loan for pro -poor women so as to address their financial problems and to be involved more in non-farm income generating activities. In other words, women should be informed about how to obtain non-farm business, how to manage non-farm business and how to attract customers.

5. Experts should provide skill training for women regarding how to deliver services to customers and create market linkage for their products, how to facilitate their work with adequate quality, and how to easily enter into non-farm work with legal ways since the majority of women practiced non-farm work via illegally. In other words, women should be informed about how to participate in non-farm jobs and negative consequences of illegality in non-farm work decisions. Thus, women can easily internalize about the issue, why non-farm activities should undertake with existing laws and regulation towards RNFA such as roadside trade, charcoal production and then improve their initiate to shift on other non-farm job, which is permitted by the law and regulations or will come into legal ways and to be environmentally friend in non-farm livelihood diversification.

\section{References}

1. World Bank (2008) Agriculture for development: World Development report 2008 Washington, DC: World Bank.

2. Babatunde RO (2013) Farm and Off-farm Works: Complement or Substitute? Evidence from Rural Nigeria. Invited paper presented at the 4th International Conference of the African Association of Agricultural Economists, September 2225, 2013, Hammamet, Tunisia.

3. FAO (Food and Agriculture Organization) (2012) Agricultural productivity growth and bridging the gap for small-family farms, Food and Agricultural Organization Inter-Agency Report to the Mexican G-20 Presidency.

4. Ellis F (2000) Rural Livelihoods and Diversity in Developing Countries. Oxford: Oxford University Press.

5. Barrett, Christopher B, Reardon, Thomas, Webb P (2001) Non-farm income diversification and household livelihood strategies in rural Africa: concepts, dynamics, and policy implications. Journal of Food Policy 26: 315-331.

6. Gordon, Ann, Craig, Catherine (2001) Rural Non-farm Activities and Poverty Alleviation in Sub-Saharan Africa. Policy Series (14). Chatham, UK: Natural Resources Institute.

7. Hussein K, Nelson J (1998) Sustainable Livelihoods and Livelihood Diversification, IDS Working Paper (69), IDS, Brighton, UK. 
8. MOFA (Ministry of Food and Agriculture) (2011) Agriculture in Ghana: Facts and Figures: SRID, Accra. Ghana.

9. DFID (2002) Non-Farm Income in Rural Areas: Key Sheets for Sustainable Livelihoods. DFID and Netherlands Ministry of Foreign Affairs, UK.

10. Barrett, Christopher B, Reardon, Thomas (2000) Asset, Activity, and Income Diversification among African Agriculturalists: Some Practical Issues, Cornell University and Michigan State University.

11. Reardon T, Delgado C, Malton P (2006) Determinants and effects of Income Diversification amongst farm Households in Burkina Faso. Journal of Development Studies 28.

12. World Bank (2003) Sustainable Development in a Dynamic World. A publication of the World Bank and the University of Oxford press. New York.

13. FAO (Food and Agriculture Organization) (2011a) The State of Food and Agriculture, 2010-2011 Rome: FAO.

14. Hill C (2011) Enabling Rural Women's Economic Empowerment: Institutions, Opportunities and Participation: Background paper prepared by UN Women In cooperation with FAO, IFAD and WFP Expert Group Meeting EGM/ RW /September 2011, Accra, Ghana.

15. Haggblade S, Hazell P, Reardon T (2010) The Rural NonFarm Economy: Prospects for Growth and Poverty Reduction. World Development 38: 1429-1441.

16. Davis B, Winters P, Reardon T, Stamoulis K (2009) Rural Non-farm Employment and Farming: Household-Level Linkages. Journal of Agricultural Economics 20: 119-123.

17. Adamu Teshome (2010) Impact of Climate change on Household Water Security and on Sustainable livelihoods in Shebel Berenta Woreda, East Gojjam Zone, Amhara Regional State, Ethiopia. Unpublished MSC Thesis, Addis Ababa University.

18. 18. Hugo Rämi (2002) Fewer surpluses in Gojjam and Awi and Severe shortages in lowland areas of Abaye River Gorge, UN-Emergencies Unit for Ethiopia; UN-OCHA Assessment Mission, October 2002 (accessed 23 April 2009).

19. Shebel Berenta Woreda Communication Affairs Office (2017) Shebel Berenta Woreda Rural Kebeles, Demographics and Socio economic features and Agro ecology report: Amharic Version.

20. Creswell JW (2003) Research Design: Qualitative, QuantitativeandMixed method approaches (2nd edition) Sage publications, University of Nebraska, Linclon.

21. Shebel Berenta Woreda Communication Affairs office (20072009 E.C) Shebel Berenta Woreda Agriculture and Rural development office: A Report on Food security and Social protection program Annual report: Amharic Version.

22. Kothari CR (2004) Research Methodology: Methods and Techniques, Jaipur, India, University of Rajasthan: New Age International.

23. Shenton, Andrew K (2004) Strategies for ensuring trustworthiness in qualitative research projects: Education for Information 22: 63-75, IOS Press Division of Information and Communication Studies, School of Informatics, Northumbria University, UK.

24. Creswell JW (2009) Research design: Qualitative, quantitative and mixed methods approach: 3rd (edition). University of Nebraska-Lincoln, Sage Publication.
25. Tesfaye Aleka (2010) Contributions, Opportunities and Constraints of Rural Non -farm activities for Households Livelihoods in Ethiopia: A case study from Sinan Woreda, Amhara Region, Unpublished Master Thesis, Addis Ababa University.

26. Yona Yohannes, Mathewos Tesfaye (2017) Assessing challenges of non-farm livelihood diversification in Boricha Wore$d$ a, Sidama zone. Journal of Development and Agricultural Economics 9: 87-96.

27. Mehta GS (2002) Non-farm economy and rural development: Sponsored by Planning Commission Government of India, New Delhi: Giri Institute of Development Studies. Lucknow.

28. Varsha T (2016) A Case Study of the Growth and Challenges of Non -Farm Activities in Gujarat. Journal of Economics and Finance 7: 73-79.

29. Food and Agriculture Organization (2017). Gender, agriculture and rural development in Armenia: Country Gender Assessment Series, Food and Agriculture Organization of the United Nations: Budapest.

30. Kazungu, Moses, Tang, Reginald G (2014) Assessing the potential of non-farm and off farm enterprises in spurring rural development in Uganda. International Journal of Agricultural Policy and Research 2: 198-202.

31. Richard N (2007) Handicrafts and Employment Generation for the Poorest Youth and Women: UNESCO, Intersect oral Programme on the Crosscutting Theme "Poverty Eradication, Especially Extreme Poverty" United Nations Educational, Scientific, and Cultural Organization, policy paper no, 17, Paris.

32. Dilruba, Khatun., Roy BC (2012) Rural Livelihood Diversification in West Bengal: Determinants and Constraints. Institute of Agriculture, Agricultural Economics Research Review 25: $115-124$.

33. Mori N (2014) Women's Entrepreneurship Development in Tanzania: Insights and recommendations: Institute of Management and Entrepreneurship Development (First Published), International Labor Offices-Geneva; ILO.

34. Inter-American Development Bank (2014) Mainstreaming gender in rural development projects in Latin America and the Caribbean / Inter-American Development Bank. Gender and Diversity Division. p. cm. (IDB Technical Note; 763).

35. Shamy C (2015) Non-farm Activities and Rural Livelihood in Tanzania: The case of Njombe District. Unpublished Master thesis, International institute of social studies, Hague, Netherlands.

36. Gessese Kune, Ignatious Mberengwa (2012) The Role of Off-and Non-Farm Activities in Achieving Sustainable Rural Livelihoods Security in Gubalafto Woreda, North Wollo Zone, Amhara Regional State, Ethiopia. Journal of Sustainable Development in Africa, 14(5), Clarion University of Pennsylvania, Clarion, Pennsylvania.

37. Tezera Mulugeta (2010) Determinants of rural household livelihood diversification: The case of Libokemkem woreda, Amhara Region. MSc thesis Addis Ababa University.

38. UNID (United Nation International Development) (1994) Women, industries entrepreneurship: Women in Industry series: the Managing Director Industrial Sectors and Environment Division United Nations Industrial Development Organization, Vienna, Austria. 
39. Ojulu L (2015) Gender Differences and Relations in Rural Household Livelihoods of Gog District, Anywaa Zone, Gambella Region, South Western Ethiopia. International Journal of Gender and Women's Studies 3: 51-79.

40. Ana Damena and Demmelash Habte (2017) Effect of Nonfarm Income on Rural Household Livelihood: A Case Study of Moyale District, Oromia Regional State, Ethiopia. American Scientific Research Journal for Engineering, Technology, and Sciences 33: 10-36.

41. Nirmala R (2015) Women Entrepreneurship: Problems, Solutions and Government Schemes for Development: Women Entrepreneurship in India. International Journal of Entrepreneurship and Business Environment Perspectives 4.

42. SARDP (Sida-Amhara Rural Development Programme) (2010) Building Ethiopia's future: The Sida-Amhara Rural
Development Programme (SARDP), Bahir Dar, Ethiopia.

43. International Financial Corporation (2014) An International Res Micro, Small, and Medium Enterprise Finance Improving Access to Finance for Women-owned Businesses in India in partnership with the Government of Japan. A research report on opportunities Challenges and the way forward: Vasant, Kunji, New Delhi, India.

44. Kumar K (1989) Conducting Key Informant Interview in Developing Countries; USAID Programme Design and Evaluation Methodology, Report (13), Washington, D.C,USAID.

45. UN (2008) Rural Women in a Changing World: Opportunities and Challenges, women 2000 and beyond: United Nations, Division for the Advancement of Women, Department of Economic and Social Affairs New York.
Copyright: (02021 Eyayu Kasseye Bayu. This is an open-access article distributed under the terms of the Creative Commons Attribution License, which permits unrestricted use, distribution, and reproduction in any medium, provided the original author and source are credited. 